\title{
Effect of proximity to the shelf edge on the diet of female Australian fur seals
}

\author{
C. L. Littnan ${ }^{1,3, *}$, J. P. Y. Arnould ${ }^{2}$, R. G. Harcourt ${ }^{1}$ \\ ${ }^{1}$ Marine Mammal Research Group, Graduate School of the Environment, Macquarie University, Sydney, \\ New South Wales 2109, Australia \\ ${ }^{2}$ School of Biological and Chemical Sciences, Deakin University, 221 Burwood Highway, Burwood, Victoria 3125, Australia \\ ${ }^{3}$ Present address: Pacific Island Fisheries Science Center (PIFSC), NOAA Fisheries, 2570 Dole Street, \\ Honolulu, Hawaii 96822, USA
}

\begin{abstract}
The Australian fur seal Arctocephalus pusillus doriferus is a temperate latitude species with a breeding distribution restricted to Bass Strait, Australia. Recent studies of the foraging behaviour of female Australian fur seals indicated that they feed demersally in the shallow continental shelf waters, a behaviour that is in contrast to the epipelagic foraging of females of most other arctocephaline (Southern Hemisphere fur seals) species and akin to that observed in sea lions. These studies, however, were conducted at one colony (Kanowna Island) located in central northern Bass Strait, and it was suggested that the observed foraging behaviour may have been due to the distance of this colony from the continental shelf edge $(180 \mathrm{~km})$, making it inefficient to forage beyond it. Here, the diet of lactating Australian fur seals was compared between 2 colonies to test if differing proximity to the continental shelf edge resulted in differences in foraging behaviour. The 2 breeding colonies studied, Kanowna Island and The Skerries, were 180 and $25 \mathrm{~km}$ from the nearest shelf edge, respectively. We analysed a total of 917 scat samples collected at the 2 colonies between 1997 and 2001. From faecal analysis, 45 primarily demersal on-shelf species of fishes and cephalopods were identified. Only 4 species had a frequency of occurrence greater than $10 \%$ : redbait Emmelichthys nitidus, jack mackerel Trachurus sp., red rock cod Pseudophycis bachus, and Gould's squid Nototodarus gouldi. No seasonal, annual or spatial differences were found between the 2 colonies, indicating that proximity to the shelf edge does not influence diet.
\end{abstract}

KEY WORDS: Arctocephalus pusillus doriferus $\cdot$ Australian fur seal $\cdot$ Diet $\cdot$ Faecal analysis $\cdot$ Bass Strait Resale or republication not permitted without written consent of the publisher

\section{INTRODUCTION}

As central-place foragers (Orians \& Pearson 1979), lactating female otariid seals (fur seals and sea lions) must balance the time and energy costs of foraging with the need to return frequently to the natal colony to nurse their dependent offspring. Otariid seal pups are totally dependent upon provisioning from their mothers until they approach weaning and must be fed at regular intervals in order to grow and survive the fasts while the mother is at sea (Bonner 1984). If the productive feeding areas are remote from the breeding colony, females must obtain prey in these areas of a quality and at a rate high enough to offset the time and energy costs involved in traveling to and from them. If travel costs are too high, then females may benefit from foraging on less abundant or nutritious prey that is in closer proximity to the breeding colony (Orians \& Pearson 1979).

Although California and Steller sea lions often forage epipelagically, lactating sea lions generally undertake short foraging trips ( 1 to $2 \mathrm{~d}$ ) during which they have a continuous dive pattern with no diel variation, foraging relatively close to the natal colony and mostly on the benthos of continental shelf areas (e.g. Costa \& Gales 2003). Prey species generally include a wide variety of 
benthic, demersal and pelagic species found at variable depths (Lalas 1997, Dellinger \& Trillmich 1999).

In contrast, female fur seals often traverse long distances to forage on pelagic prey in the mid-water mixing layer in the vicinity of oceanic frontal structures or upwelling regions associated with continental shelf edges, though some on-shelf foraging does occur (Antonelis et al. 1990, Ochoa-Acuña \& Francis 1995, Green et al. 1998, Harcourt et al. 2002, Lea et al. 2002). They exploit patches of high oceanic productivity, traversing the continental shelf to feed over the continental slope (or beyond) and forage mostly at night on vertically migrating prey in structured dive-bouts (e.g. Boyd 1996, Harcourt et al. 2002). For example, myctophid fish and onychoteuthid squids are significant components in the diet of the Juan Fernandez fur seal (Ochoa-Acuña \& Francis 1995), New Zealand fur seal Arctocephalus forsteri (Harcourt et al. 2002) and Galapagos fur seals (Dellinger \& Trillmich 1999). Female Antarctic fur seals A. gazella feed almost exclusively on pelagic species; for example, colonies at Heard (Green et al. 1998) and Kerguelen Islands feed primarily on myctophid fish (Lea et al. 2002), and the population at South Georgia Island feeds on krill Euphausia superba (Croxall et al. 1985, Reid \& Arnould 1996). The sizes of these species' prey tend to be smaller than those of sea lions and range between 3 and $14 \mathrm{~cm}$ (e.g. Dellinger \& Trillmich 1999).

The Australian fur seal Arctocephalus pusillus doriferus is a temperate latitude species with a breeding distribution restricted to Bass Strait, between the south-eastern tip of the Australian mainland and Tasmania (Kirkwood et al. 2005; see Fig. 1). Recent studies of the foraging behaviour of female Australian fur seals indicated that they begin diving soon after leaving the colony, dive throughout the foraging trip at all times of the day or night with no bout structure, and feed demersally in the shallow continental shelf waters of Bass Strait (Arnould \& Hindell 2001, Littnan \& Arnould 2002). This foraging behaviour is in stark contrast to that of other female arctocephaline (Southern Hemisphere fur seals) species and is akin to that observed in sea lions (Renouf 1991, Gales \& Mattlin 1997, Costa \& Gales 2003). These studies on Australian fur seal foraging, however, were conducted at one colony (Kanowna Island) located in central northern Bass Strait (see Fig. 1), and it was suggested that the observed foraging behaviour may have been due to the distance of this colony from the continental shelf edge $(180 \mathrm{~km})$, making it inefficient to forage beyond it (Arnould \& Hindell 2001).

The Australian fur seal currently breeds at 9 locations in Bass Strait, of which 4 occur within $100 \mathrm{~km}$ of the continental shelf edge and the potentially more productive waters of the East Australia Current to the east and the Bonney Upwelling to the west (Schahinger 1987). It might be expected, therefore, that the proximity of these colonies to the continental shelf edge would make foraging pelagically in upwelling regions over the continental slope (like other arctocephaline species) energetically or nutritionally profitable. Consequently, differences in foraging ecology between fur seals from colonies close to the continental shelf edge and those in central Bass Strait should be reflected in their diets.

Earlier studies reported that the Australian fur seal has a varied diet of demersal and pelagic species consisting of jack mackerel Trachurus declivis, redbait Emmelichthys nitidus, leatherjackets (Monocanthidae), barracouta Thyrsites atun, and invertebrates such as Gould's squid Nototodarus gouldi, rock lobster Jasus lalandii and a number of octopus species (Lewis 1930, Gales et al. 1993, Gales \& Pemberton 1994, Hume et al. 2004). These earlier studies were conducted mainly at haul-out sites where fur seals of both sexes and multiple age classes occur. Any difference in diet between different haul-outs might be a function of age and sex class composition of the seals on land at time of sampling, rather than regional or ecological differences. In the present study, we used faecal analysis to investigate the diet of Australian fur seals at locations within breeding colonies that consisted almost entirely of adult females and their pups during the study period. Any dietary differences between sites are therefore likely to reflect differences in feeding ecology induced by differences in the marine environment such as proximity to the shelf edge, rather than the composition of the colony. Furthermore, seasonal changes in the diet of other fur seal species have been reported to occur in relation to seasonal prey abundance (e.g. Georges et al. 2000, Harcourt et al. 2002). We therefore compared female diet at both sites for all 4 seasons.

\section{MATERIALS AND METHODS}

Study site and sample collection. The diet of female Australian fur seals was investigated between 1997 and 2000 at Kanowna Island (central Bass Strait, $39^{\circ} 10^{\prime} \mathrm{S}, 146^{\circ} 18^{\prime} \mathrm{E}, 180 \mathrm{~km}$ from the shelf edge) and between 1999 and 2001 at The Skerries (eastern Bass Strait, $37^{\circ} 45^{\prime} \mathrm{S}, 149^{\circ} 31^{\prime} \mathrm{E}, 25 \mathrm{~km}$ from the shelf edge; Fig. 1). These colonies have annual pup productions of 2301 and 2486, respectively (Kirkwood et al. 2005).

The collection of faecal and regurgitate samples was timed to sample each season at least once per year with seasons defined as: summer (December-February), autumn (March-May), winter (June-August), and spring (September-November; see Table 1). Care 


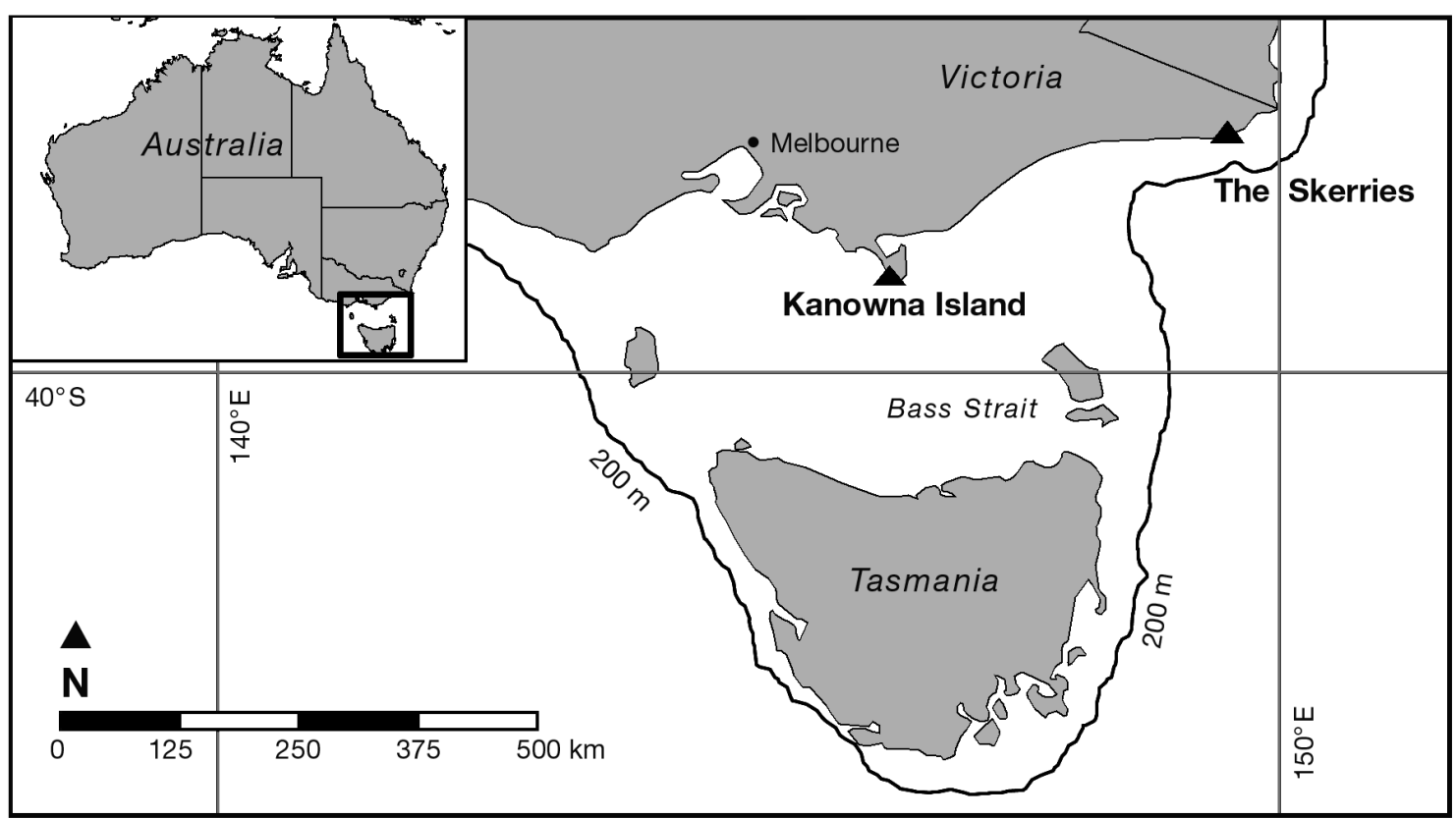

Fig. 1. Location of the 2 Australian fur seal breeding colonies investigated in this study: Kanowna Island and The Skerries. The solid black line represents the continental shelf break (200 m isobath)

was taken to collect samples from parts of the natal colonies frequented almost exclusively by lactating females. Samples were stored frozen $\left(-20^{\circ} \mathrm{C}\right)$ individually in plastic bags until analysis.

In the laboratory, faeces were thawed and then placed in plastic sample containers filled with soapy water. The samples were allowed to soak for at least $48 \mathrm{~h}$ and were repeatedly and intermittently gently shaken. Regurgitate samples were thawed prior to

Table 1. Arctocephalus pusillus doriferus. Number of faecal and regurgitate samples collected at 2 Australian fur seal breeding colonies: Kanowna Island ( $\mathrm{n}=11$ trips) and The Skerries ( $\mathrm{n}=9$ trips)

\begin{tabular}{|lrrrr|}
\hline \multirow{2}{*}{ Date } & \multicolumn{2}{c}{ Kanowna } & \multicolumn{2}{c|}{ The Skerries } \\
& Faeces & Regurgitate & Faeces & Regurgitate \\
\hline Winter 97 & 50 & 6 & - & - \\
Summer 98 & 30 & 7 & - & - \\
Autumn 98 & 35 & 0 & - & - \\
Winter 98 & 53 & 3 & - & - \\
Spring 98 & 41 & 5 & - & - \\
Summer 99 & 18 & 5 & 47 & 5 \\
Autumn 99 & 54 & 6 & 56 & 6 \\
Winter 99 & 77 & 6 & 16 & 3 \\
Spring 99 & 40 & 2 & 57 & 11 \\
Summer 00 & 35 & 7 & 66 & 0 \\
Autumn 00 & - & - & 29 & 4 \\
Winter 00 & 35 & 4 & 66 & 5 \\
Spring 00 & - & - & 50 & 2 \\
Summer 01 & - & - & 62 & 5 \\
Total & 468 & 51 & 449 & 41 \\
\hline
\end{tabular}

analysis. Samples were then separated through a series of sieves of decreasing mesh widths $(2.0,1.0$, and $0.2 \mathrm{~mm}$ ). Sagital otoliths, teeth and jaws of fish and cephalopod beaks were collected with tweezers, washed in $70 \%$ ethanol, and stored dried.

Species identifications and habitat designation were facilitated using reference atlases (Clarke 1986, Kailola et al. 1993, D. Furlani unpubl. data) and collections from the Australian Museum (Sydney) and Museum Victoria (Melbourne). Prey remains were identified to genus and species whenever possible. Some species, mainly jack mackerel Trachurus declivis, yellowtail T. novaezelandiae and red bait Emmelichthys nitidus are difficult to differentiate when partially eroded; therefore, undetermined specimens of these species were pooled into a separate category for analysis (Trachurus/Emmelichthys). Broken and otherwise unidentifiable otoliths and beaks were recorded but not used in analyses. Otolith and beak frequencies were identified for each individual faecal sample. Only intact otoliths with good surface structure, deep succulus and ostii showing little degradation were measured for size estimates. Most fish were identified to species except in cases where otoliths were too similar (Triglidae, Monocanthidae), or when other remains, such as teeth, were used to identify taxa (Monocanthidae). It is difficult to distinguish southern keeled octopus and pale octopus using beaks (Hume et al. 2004); therefore, the 2 species were grouped for analyses and are referred to as pale octopus. The same is true for jack mackerel and yellowtail and will hereafter be referred to as jack mackerel. 
Statistical analyses. To evaluate the importance of each prey type in the diet of female Australian fur seals, we calculated the indices frequency of occurrence (FoO) and numerical abundance (NA). Due to the scarcity of regurgitates from each season, only faecal samples were used for statistical analyses. A randomisation chi-square test (Manly 1997) in the statistical software package RT 2.1 was used to test whether spatial and/or temporal differences in diet composition (FoO and biomass) existed. A series of 10000 randomisations was used to test how randomly computed chi-square values compared to group total chi-square values. Chi-square results are presented as the percentage of randomisations less than the null hypothesis (n.h.).

Analysis of similarities (ANOSIM) was also used to test for variation in species composition of diet between location, season, and year. ANOSIM is a nonparametric permutation applied to a similarity matrix and combined with a general randomisation approach for the generation of significance levels (Clark \& Warwick 1994). ANOSIM is useful for comparing the structure of entire species assemblages (all species combined) and is a non-parametric analogue to the more traditional multivariate analysis of variance (MANOVA) but with no associated assumptions. All species occurring in $>2 \%$ of faecal samples at either colony were used. If none of the test species occurred in a faecal sample, it was removed from the analysis. Spatial comparisons were made only for periods in which samples were collected from both colonies. Seasonal comparisons were made separately for each colony. Unless otherwise stated, all data are presented as mean $\pm \mathrm{SE}$.

Prey size and biomass. Intact beaks and otoliths were collected and measured to estimate the length and mass range of species in the diet. Due to the high level of breakage and erosion of remains in faecal samples, few species had sample sizes large enough to use in comparisons between location, season and sample type. When sample sizes were viable, $t$-tests were used to compare beak and oto-lith sizes between locations. Analyses of variance (ANOVA) were used to compare seasonal variation in prey size. Due to multiple comparisons, the $\alpha$ values were set at 0.01 .

Fish length (standard or fork) and estimated wet weight were calculated using equations from unpublished regressions (Furlani et al. 2000, D. Furlani unpubl. data). Both otolith length and weight were used to estimate the length $(\mathrm{cm})$ and mass $(\mathrm{g})$ of prey items. Species-specific relationships between otolith size and body mass were available for 24 of the frequently occurring prey species. For jack mackerel and yellowtail, which have similar physiological, behavioural and developmental characteristics (Kailola et al. 1993, Furlani et al. 2000), a single species regression was used. Biomass estimates for season and location were calculated by applying the mean mass of each species to the numerical abundance of that species per faecal sample. The individual species masses were then summed and divided by the total mass of all species to provide an estimate of relative biomass consumed.

\section{RESULTS}

\section{Sample description}

In total, 468 faecal and 51 regurgitate samples were collected during 11 sampling periods on Kanowna Island between August 1997 and June 2000 (Table 1). Of these samples, $102(19.6 \%)$ contained no identifiable prey remains, and $20(3.0 \%)$ contained no remains at all. In total, 449 faecal and 41 regurgitate samples were collected during 9 sampling periods at The Skerries between January 1999 and January 2001 (Table 1). Of these, 76 (15.6\%) had no diagnostic prey remains, and $31(6.0 \%)$ contained no remains at all.

In total, 3274 otoliths were recovered from faeces and regurgitates, of which 2356 were used for species identification (2151 and 205 from faeces and regurgitates, respectively). We collected 576 upper and 541 lower beaks, with 161 lower beaks (29.8\%) found in regurgitates and $380(70.2 \%)$ in faecal samples for all prey species combined. Summaries of the prey species and their abundance indices in faecal and regurgitate samples for each colony are given in Tables $2 \& 3$, respectively.

\section{Diet composition}

A total of 38 fish taxa and a minimum of 7 cephalopod species were identified as prey items of female Australian fur seals. All taxa (45) found in the diet were identified in faecal samples (Table 2), while regurgitate samples contained only 25 species (Table 3 ). Classification of prey according to their known marine habitats indicated that $39(87 \%)$ were neritic, 4 (9\%) pelagic (meaning, in this case, shelf-break and beyond), 33 (73\%) species were demersal, and 14 (31\%) inhabited the water column. Several species are known to occur in multiple marine habitat classifications.

Both colonies were characterised by 3 to 4 taxa occurring more than $10 \%$ of the time, 11 or 12 taxa occurring in 2 to $10 \%$ of samples, and the remaining species occurring infrequently $(<2 \%)$. Jack mackerel and redbait occurred frequently at both colonies, with redbait occurring in 30.6 and $20.9 \%$, and jack mackerel in 25.8 and $24.1 \%$ of samples from Kanowna and The Sker- 
Table 2. Species, frequency of occurrence (FoO), numerical abundance (NA), and mean and range of prey remains found in Arctocephalus pusillus doriferus faecal samples from Kanowna Island and The Skerries. The Trachurus/Emmelichthys group represents otoliths that could not be differentiated between the 2 groups. All $\mathrm{n}$ values represent the number of samples in which each species occurred. Habitat classifications (H.C.) represent location in the water column and location in relation to the continental shelf: $\mathrm{D}$, benthic/demersal; $\mathrm{C}$, mid- or upper water

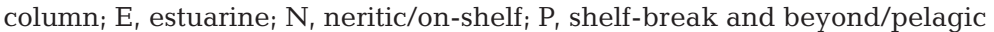

\begin{tabular}{|c|c|c|c|c|c|c|c|c|c|c|c|c|}
\hline \multirow[t]{3}{*}{ Common name } & \multirow[t]{3}{*}{ Species } & \multirow[t]{3}{*}{ H.C. } & \multicolumn{4}{|c|}{ _Kanowna Island } & \multicolumn{4}{|c|}{ The Skerries -} & \multirow[t]{3}{*}{ Mean } & \multirow[t]{3}{*}{ Range } \\
\hline & & & \multicolumn{2}{|c|}{ FoO } & \multicolumn{2}{|c|}{ NA } & \multicolumn{2}{|c|}{$\mathrm{FoO}$} & \multicolumn{2}{|c|}{ NA } & & \\
\hline & & & (n) & $(\%)$ & (n) & $(\%)$ & (n) & $(\%)$ & $(\mathrm{n})$ & $(\%)$ & & \\
\hline Redbait & Emmelichthys nitidus $^{\mathrm{a}}$ & $\mathrm{C}, \mathrm{N}$ & 106 & 30.37 & 317 & 23.10 & 72 & 20.93 & 242 & 24.80 & 3 & $2-45$ \\
\hline Rock cod & Pseudophycis bachus $^{\mathrm{a}}$ & $\mathrm{D}, \mathrm{N}$ & 92 & 26.36 & 234 & 17.06 & 23 & 6.69 & 52 & 5.33 & 3 & $1-19$ \\
\hline Jack mackerel & Trachurus spp. ${ }^{a}$ & $\mathrm{C}, \mathrm{N}$ & 90 & 25.79 & 250 & 18.22 & 83 & 24.13 & 248 & 25.11 & 3 & $1-18$ \\
\hline Arrow squid & Nototodarus gouldi ${ }^{\mathrm{a}}$ & $\mathrm{C}, \mathrm{N}$ & 41 & 11.75 & 107 & 7.80 & 43 & 12.50 & 57 & 5.84 & 2 & $1-15$ \\
\hline Pale octopus & Octopus berrima/pallidus ${ }^{\mathrm{a}}$ & $\mathrm{D}, \mathrm{N}$ & 28 & 8.02 & 30 & 2.19 & 15 & 4.36 & 18 & 1.84 & 2 & $1-9$ \\
\hline Maori octopus & Octopus maorum ${ }^{\mathrm{a}}$ & $\mathrm{D}, \mathrm{N}$ & 26 & 7.45 & 29 & 2.11 & 21 & 6.10 & 27 & 2.77 & 1 & $1-3$ \\
\hline \multirow{2}{*}{ Barracouta } & Thyristes atun ${ }^{\mathrm{a}}$ & $\mathrm{D}, \mathrm{C}, \mathrm{N}$ & 23 & 6.59 & 37 & 2.70 & 12 & 3.49 & 16 & 1.64 & 2 & $1-11$ \\
\hline & Trachurus/Emmelichthys & & 23 & 6.59 & 56 & 4.08 & 30 & 0.58 & 69 & 7.07 & 1 & $1-9$ \\
\hline Leatherjackets & Monocanthidae $^{\mathrm{a}}$ & $\mathrm{D}, \mathrm{N}$ & 22 & 6.30 & 25 & 1.82 & 10 & 2.91 & 10 & 1.02 & 1 & $1-2$ \\
\hline Tiger flathead & Neoplatycephlus richardsoni ${ }^{\mathrm{a}}$ & $\mathrm{D}, \mathrm{N}$ & 19 & 5.44 & 29 & 2.11 & 8 & 2.33 & 10 & 1.02 & 1 & $1-5$ \\
\hline Butteryfly gurnard & Leptidotriglia spp. ${ }^{\mathrm{a}}$ & $\mathrm{D}, \mathrm{N}$ & 15 & 4.30 & 33 & 2.41 & 4 & 1.16 & 6 & 0.61 & 2 & $1-6$ \\
\hline Silverbelly & Parequula melbournensis ${ }^{\mathrm{a}}$ & $\mathrm{D}, \mathrm{N}$ & 12 & 3.44 & 28 & 2.04 & 8 & 2.33 & 9 & 0.92 & 2 & $1-9$ \\
\hline Giant cuttlefish & Sepia apama ${ }^{a}$ & $\mathrm{D}, \mathrm{N}$ & 11 & 3.15 & 12 & 0.87 & 14 & 4.07 & 15 & 1.54 & 1 & $1-2$ \\
\hline Redfish & Centroberyx affinis $^{\mathrm{a}}$ & $\mathrm{C}, \mathrm{N}$ & 8 & 2.29 & 52 & 3.79 & 6 & 1.74 & 14 & 1.43 & 4 & $1-37$ \\
\hline Red gurnard & Chelidonichthys kumu ${ }^{\mathrm{a}}$ & $\mathrm{D}, \mathrm{N}$ & 7 & 2.01 & 13 & 0.95 & - & 0.00 & - & 0.00 & 2 & $1-5$ \\
\hline Gemfish & Rexea solandri ${ }^{\mathrm{a}}$ & $\mathrm{C}, \mathrm{D}, \mathrm{N}, \mathrm{P}$ & 7 & 2.01 & 14 & 1.02 & 1 & 0.29 & 5 & 0.51 & 2 & $1-5$ \\
\hline Southern calamari & Sepioteuthis australis & $\mathrm{C}, \mathrm{D}, \mathrm{N}$ & 6 & 1.72 & 6 & 0.44 & 2 & 0.58 & 3 & 0.31 & 2 & $1-5$ \\
\hline Gurnard spp. & Triglidae & $\mathrm{D}, \mathrm{N}$ & 6 & 1.72 & 19 & 1.38 & 2 & 0.00 & 5 & 0.51 & 4 & $1-8$ \\
\hline Barber perch & Casioperca rasor & $\mathrm{D}, \mathrm{N}$ & 4 & 1.15 & 6 & 0.44 & 4 & 1.16 & 10 & 1.02 & 2 & $1-4$ \\
\hline Grey morwong & Nemadactylus douglasii & $\mathrm{D}, \mathrm{N}$ & 4 & 1.15 & 4 & 0.29 & 2 & 0.58 & 4 & 0.41 & 1 & $1-3$ \\
\hline Silver trevally & Pseudocaranx dentex ${ }^{\mathrm{a}}$ & $\mathrm{C}, \mathrm{N}$ & 4 & 1.15 & 6 & 0.44 & 8 & 2.33 & 24 & 2.46 & 3 & $1-6$ \\
\hline Eastern school whiting & Sillgo flindersi ${ }^{\mathrm{a}}$ & $\mathrm{D}, \mathrm{N}$ & 4 & 1.15 & 5 & 0.36 & 10 & 2.91 & 26 & 2.66 & 2 & $1-8$ \\
\hline Sand flathead & Platycephalus bassensis & $\mathrm{D}, \mathrm{N}$ & 3 & 0.86 & 5 & 0.36 & 2 & 0.58 & 3 & 0.31 & 2 & $1-3$ \\
\hline Cuttlefish & Sepia novaehollandiae & $\mathrm{D}, \mathrm{C}, \mathrm{N}$ & 3 & 0.86 & 3 & 0.22 & - & 0.00 & - & 0.00 & 1 & 1 \\
\hline King George whiting & Sillagnoides punctata & $\mathrm{C}, \mathrm{N}$ & 3 & 0.86 & 4 & 0.29 & 5 & 1.45 & 6 & 0.61 & 1 & $1-2$ \\
\hline Goatfish & Upenichthys spp. & $\mathrm{D}, \mathrm{N}$ & 3 & 0.86 & 21 & 1.53 & - & 0.29 & - & 0.00 & 2 & $1-3$ \\
\hline Australian salmon & Arripis trutta & $\mathrm{D}, \mathrm{N}$ & 2 & 0.57 & 2 & 0.15 & - & 0.00 & - & 0.00 & 1 & 1 \\
\hline Gurnard perch & Neobastes scorpaenoides & $\mathrm{D}, \mathrm{N}$ & 2 & 0.57 & 2 & 0.15 & 1 & 0.29 & 1 & 0.10 & 1 & 1 \\
\hline Tailor & Pomatomus saltatrix ${ }^{\mathrm{a}}$ & $\mathrm{C}, \mathrm{N}$ & 2 & 0.57 & 10 & 0.73 & 9 & 2.62 & 29 & 2.97 & 3 & $1-9$ \\
\hline Black bream & Acanthopagrus butcheri & $\mathrm{C}, \mathrm{E}$ & 1 & 0.29 & 1 & 0.07 & 1 & 0.29 & 3 & 0.31 & 4 & $1-12$ \\
\hline Yelloweye mullet & Aldrichetta forsteri & $\mathrm{C}, \mathrm{E}$ & 1 & 0.29 & 5 & 0.36 & 1 & 0.29 & 1 & 0.10 & 3 & $1-5$ \\
\hline Pink ling & Genypterus blacodes & $\mathrm{D}, \mathrm{N}$ & 1 & 0.29 & 2 & 0.15 & 5 & 1.45 & 15 & 1.54 & 3 & $1-8$ \\
\hline Pygmy octopus & Octopus supercilious & $\mathrm{D}, \mathrm{N}$ & 1 & 0.29 & 1 & 0.07 & 1 & 0.29 & 1 & 0.10 & 1 & 1 \\
\hline Yank flathead & Platycephalus speculata & $\mathrm{D}, \mathrm{E}$ & 1 & 0.29 & 1 & 0.07 & - & 0.00 & - & 0.00 & 1 & 1 \\
\hline Hapuku & Polyprion oxygenios & $\mathrm{C}, \mathrm{N}, \mathrm{P}$ & 1 & 0.29 & 3 & 0.22 & 1 & 0.29 & 1 & 0.10 & 1 & $1-2$ \\
\hline Silver warehou & Seriolella punctata & $\mathrm{D}, \mathrm{N}$ & 1 & 0.29 & 1 & 0.07 & 6 & 1.74 & 11 & 1.13 & 2 & $1-2$ \\
\hline Cardinal fish & Apoginidae & $\mathrm{D}, \mathrm{N}$ & - & 0.00 & - & 0.00 & 1 & 0.29 & 1 & 0.10 & 1 & 1 \\
\hline Mado & Atypichthlys strigatus & $\mathrm{D}, \mathrm{N}$ & - & 0.00 & - & 0.00 & 2 & 0.58 & 2 & 0.20 & 1 & 1 \\
\hline Luderick & Girella tricuspidata & $\mathrm{D}, \mathrm{E}$ & - & 0.00 & - & 0.00 & 2 & 0.58 & 9 & 0.92 & 4 & $1-7$ \\
\hline Reef ocean perch & Helicolenus percoides & $\mathrm{D}, \mathrm{N}, \mathrm{P}$ & - & 0.00 & - & 0.00 & 3 & 0.87 & 3 & 0.31 & 1 & 1 \\
\hline Crested flounder & Lophonectes gallus & $\mathrm{D}, \mathrm{N}$ & - & 0.00 & - & 0.00 & 5 & 1.45 & 9 & 0.92 & 2 & $1-3$ \\
\hline Common bullseye & Permaperca multivariata & $\mathrm{D}, \mathrm{N}$ & - & 0.00 & - & 0.00 & 1 & 0.29 & 9 & 0.92 & 9 & 9 \\
\hline Dusky flathead & Platycephalus fuscus & $\mathrm{D}, \mathrm{N}$ & - & 0.00 & - & 0.00 & 1 & 0.29 & 1 & 0.10 & 1 & 1 \\
\hline John dory & Zeus faber & $\mathrm{D}, \mathrm{N}, \mathrm{P}$ & - & 0.00 & - & 0.00 & 1 & 0.29 & 1 & 0.10 & 1 & 1 \\
\hline
\end{tabular}

ries, respectively. The primary cephalopod component at the 2 locations was Gould's squid, which occurred in 11.8 and $12.5 \%$ of samples collected from Kanowna and The Skerries, respectively. The greatest discrepancy between the 2 locations was the prevalence of red rock cod, with an FoO of $19.2 \%$ at Kanowna and $6.7 \%$ at The Skerries.

\section{Prey size and biomass estimates}

From a total of 2151 otoliths collected from faecal samples, 841 (39.1\%) were in good condition and could be used to estimate prey size. Otolith length and weight were recorded for 31 species, but samples were heavily biased towards 5 species: jack mackerel 
Table 3. Species, frequency of occurrence (FoO), and numerical abundance (NA) of prey found in Arctocephalus pusillus doriferus regurgitate samples from Kanowna Island and The Skerries. The Trachurus/Emmelichthys group represents otoliths that could not be differentiated between the 2 groups. All $n$ values represent the number of samples in which each species occurred

\begin{tabular}{|c|c|c|c|c|c|c|c|c|}
\hline \multirow[t]{3}{*}{ Species } & \multicolumn{4}{|c|}{ - Kanowna Island- } & \multicolumn{4}{|c|}{ - The Skerries } \\
\hline & \multicolumn{2}{|c|}{$\mathrm{FoO}$} & \multicolumn{2}{|c|}{ NA } & \multicolumn{2}{|c|}{ FoO } & \multicolumn{2}{|c|}{ NA } \\
\hline & (n) & $(\%)$ & (n) & $(\%)$ & (n) & $(\%)$ & (n) & $(\%)$ \\
\hline Redbait & 20 & 41.67 & 40 & 13.79 & 17 & 43.59 & 33 & 18.54 \\
\hline Gould's squid & 20 & 41.67 & 94 & 32.41 & 23 & 58.97 & 36 & 20.22 \\
\hline Pale octopus & 20 & 41.67 & 29 & 10.00 & 16 & 41.03 & 18 & 10.11 \\
\hline Red rock cod & 20 & 41.67 & 35 & 12.07 & 1 & 2.56 & 1 & 0.56 \\
\hline Jack mackerel & 20 & 41.67 & 27 & 9.31 & 19 & 48.71 & 19 & 10.67 \\
\hline Southern calamari & 16 & 33.33 & 12 & 4.14 & - & - & 0 & - \\
\hline Giant cuttlefish & 14 & 29.17 & 5 & 1.72 & 13 & 33.33 & 1 & 0.56 \\
\hline Redfish & 12 & 25.00 & 14 & 4.83 & 1 & 2.56 & 5 & 2.81 \\
\hline Dusky flathead & 10 & 20.83 & 1 & 0.34 & 2 & 5.12 & 2 & 1.12 \\
\hline Cuttlefish & 10 & 20.83 & 1 & 0.34 & 1 & 2.56 & 1 & 0.56 \\
\hline Maori octopus & 8 & 16.67 & 17 & 5.86 & 19 & 48.72 & 17 & 9.55 \\
\hline Tiger flathead & 6 & 12.50 & 3 & 1.03 & 14 & 35.90 & 7 & 3.93 \\
\hline Red mullet & 6 & 12.50 & 5 & 1.72 & - & - & 0 & - \\
\hline Butterfly gurnard & 2 & 4.17 & 2 & 0.69 & - & - & 0 & - \\
\hline Pygmy octopus & 2 & 4.17 & 1 & 0.34 & 1 & 2.56 & 1 & 0.56 \\
\hline Red gurnard & 1 & 2.08 & 1 & 0.34 & - & - & 0 & - \\
\hline Silverbelly & 1 & 2.08 & 2 & 0.69 & 1 & 2.56 & 1 & 0.56 \\
\hline Black bream & - & - & - & - & 10 & 25.64 & 1 & 0.56 \\
\hline Pink ling & - & - & - & - & 4 & 10.25 & 7 & 3.93 \\
\hline Crested flounder & - & - & - & - & 5 & 12.82 & 15 & 8.43 \\
\hline Grey morwong & - & - & - & - & 2 & 5.12 & 3 & 1.69 \\
\hline Gemfish & - & - & - & - & 1 & 2.56 & 1 & 0.56 \\
\hline Eastern school whiting & - & - & - & - & 13 & 33.33 & 4 & 2.25 \\
\hline Barracouta & - & - & - & - & 2 & 5,12 & 2 & 1.12 \\
\hline Trachurus/Emmelichthys & 1 & 2.08 & 1 & 0.34 & 2 & 5.12 & 3 & 1.69 \\
\hline
\end{tabular}

$(t=1.08, \mathrm{p}=0.68)$. Gould's squid could only be compared among summer, autumn and winter, and no difference in size was found $(F=2.33, \mathrm{p}=0.13)$. Seasonal comparisons of size for pale octopus could only be conducted for summer and winter, and no difference in prey size was detected $(t=-1.28, \mathrm{p}=0.19)$.

In biomass reconstruction, larger prey items are likely to form a larger component of the biomass than smaller items, even if the latter may occur at much higher frequencies. Table 4 shows a comparison of the rankings of prey items by FoO and estimated \% biomass of the diet for all seasons combined at both colonies.

\section{Spatial and seasonal comparison}

The FoO among location, season and year were compared to test if the abundance of some species of fishes and cephalopods in the diet differs spatially, due to variation in foraging habitat, or temporally, due to fluctuations caused by seasonal movements or other environmental factors (Tables 5 \& 6). Neither ANOSIM nor chi-square analyses indicated significant seasonal, annual, $(\mathrm{n}=216 ; 25.7 \%)$, red rock cod $(\mathrm{n}=198 ; 23.5 \%)$, redbait ( $\mathrm{n}=198 ; 23.5 \%)$, redfish $(\mathrm{n}=49 ; 5.8 \%)$ and tiger flathead ( $\mathrm{n}=48 ; 5.8 \%$ ). Prey size was compared between locations for these 4 species by pooling samples at each colony. No differences in otolith size were found for any fish species (unpaired $t$-tests; jack mackerel $t=-0.32, \mathrm{p}=0.75$; redbait $t=1.15, \mathrm{p}=0.26$; redfish $t=$ $0.47, \mathrm{p}=0.64 ;$ red rock cod $t=-0.83, \mathrm{p}=0.41$ ).

Prey size was compared between seasons by pooling samples from both colonies within season to ensure sufficient sample sizes for comparison. Seasonal differences in otolith size could only be tested for 4 species. Significant seasonal differences were found for redbait and jack mackerel $(F=4.74, \mathrm{p}=0.004 ; F=8.84, \mathrm{p}=$ 0.01 , respectively), but not for red rock cod or tiger flathead $(F=4.84, \mathrm{p}=0.18 ; F=13.43, \mathrm{p}=0.29$, respectively).

Of the 541 lower beaks identified in the samples, 306 $(57 \%)$ were in suitable condition for measuring. Cephalopod beaks were heavily biased towards Gould's squid ( $\mathrm{n}=156 ; 51 \%$ ) and pale octopus $(\mathrm{n}=58 ; 19 \%)$, and only these could be used for limited seasonal and spatial comparisons of prey size. No difference in size of prey between colonies was found for these 2 species or spatial differences in the diet composition of the seals.

Results from temporal and spatial analysis of variation in the biomass composition of diet corroborated the results from FoO analyses. No differences were found among location, seasons or years (Table 5).

\section{DISCUSSION}

\section{Limitations of data collected}

Inferring diet from otoliths and beaks in faeces and regurgitates is potentially subject to bias due to differential ingestion, retention, and digestion (reviewed by Pierce \& Boyle 1991). The results of the present study are based on the assumptions that ratios of prey items in faeces and regurgitates (1) were unbiased (i.e. no differential otolith degradation or retention), and (2) represented the ratios of prey items ingested at different stages of the foraging trips.

The accumulation of cephalopod beaks in the stomachs over a period of time is a potential bias in scat analysis (Bigg \& Fawcett 1985, Gales \& Cheal 1992). 
Table 4. Diet composition by frequency of occurrence (FoO) and reconstituted biomass of prey of Arctocephalus pusillus doriferus at both colonies (Kanowna Island and The Skerries). Regressions for calculating size were not available for some species

\begin{tabular}{|lrlc|}
\hline Species & FoO $(\%)$ & Species & Biomass (\%) \\
\hline Redbait & 25.65 & Jack mackerel & 16.03 \\
Jack mackerel & 24.96 & Gould's squid & 14.07 \\
Rock cod & 16.53 & Redbait & 13.27 \\
Gould's squid & 12.13 & Maori octopus & 11.48 \\
Trachurus/Emmelichthys & 7.66 & Southern calamari & 8.63 \\
Maori octopus & 6.78 & Tiger flathead & 8.10 \\
Pale octopus & 6.24 & Rock cod & 5.73 \\
Barracouta & 5.04 & Barracouta & 5.08 \\
Monocanthidae & 4.61 & Pale octopus & 3.55 \\
Tiger flathead & 3.89 & Trachurus/Emmelichthys & 3.36 \\
Southern calamari & 3.61 & & \\
Silverbelly & 2.89 & & \\
Leptidotriglia spp. & 2.15 & & \\
\hline
\end{tabular}

These beaks, which can represent several meals, are voided when seals regurgitate. In this study, we looked for regurgitated matter during our scat sampling and found few samples compared to faecal samples. If we assume that the probabilities of defecating and regurgitating on the beach are the same, then the regurgitation of beaks may not be a major bias in this species given the low prevalence. Ochoa-Acuña \& Francis (1995) suggested that regurgitation may be more frequent for only a few hours after feeding; thus the absence of regurgitated matter at the colonies may be a factor of the distance of foraging areas from the colony. An additional bias with using cephalopod beaks is the potential for the retention of larger beaks due to the size of the pyloric sphincter (Pierce \& Boyle 1991, Gales \& Cheal 1992). Upon analysis, we found that for some species of cephalopods in the diet of Aus-

Table 5. Arctocephalus pusillus doriferus. Analyses of similarities (ANOSIM) in diet between location, season, and years for Australian fur seals at Kanowna Island (K) and The Skerries $(\mathrm{S}) . \%<\mathrm{n}$.h.: percentage of randomisations less than the null hypothesis

\begin{tabular}{|lcccc|}
\hline \multirow{2}{*}{ Comparison } & \multicolumn{2}{c}{ Chi-square } & \multicolumn{2}{c|}{ ANOSIM } \\
& $\%<$ n.h. & $\mathrm{p}$ & $\mathrm{R}$ & $\mathrm{p}$ \\
\hline FoO & & & & \\
Location & 80 & 0.84 & -0.0004 & 0.65 \\
Season (K) & 93 & 0.88 & 0.0012 & 0.28 \\
Season (S) & 85 & 0.86 & 0.0009 & 0.21 \\
Year & 73 & 0.70 & 0.12 & 0.11 \\
Biomass & & & & \\
Location & 90 & 0.88 & 0.0007 & 0.55 \\
Season (K) & 93 & 0.91 & 0.001 & 0.31 \\
Season (S) & 89 & 0.90 & 0.001 & 0.31 \\
Year & 84 & 0.85 & 0.07 & 0.19 \\
\end{tabular}

tralian fur seals, larger beaks were retained in the gut and expelled in vomit. Therefore, the size of cephalopod prey may be underestimated by using scats alone.

Passage rates of free-ranging Australian fur seals are unknown, but both female and male fur seals are known to forage for an average of 6 to $8 \mathrm{~d}$ (Arnould \& Hindell 2001, Kirkwood et al. 2002, Littnan \& Arnould 2002). In preliminary studies of passage rate times for captive Australian fur seals, ingested beads passed through the alimentary canal within 24 to $48 \mathrm{~h}$ (J. Tripovich pers. comm.), and it is possible that prey ingested by Australian fur seals early in a foraging trip are voided by the time they return to shore. Alternatively, the lack of diagnostic remains in many scats may be due to gastroliths in the stomachs of fur seals that can crush and erode remains and is a problem in scat analysis of other otariids such as the Australian sea lion Neophoca cinerea (Gales \& Cheal 1992). Regurgitates of Australian fur seals have been found containing gastroliths at both colonies (C. L. Littnan pers. obs.).

Arnould \& Hindell (2001) reported that female Australian fur seals showed neither diel variation in dive behaviour (depth or frequency) nor preference in foraging location (i.e. travelling to a particular area before commencing diving) but that they dove throughout foraging trips to maximum depths representative of the regions traversed (Arnould \& Hindell 2001). It is possible, therefore, that individuals have an equal probability of encountering most prey items at any point in the foraging trip such that faecal and regurgitate samples are representative of the general diet.

\section{Australian fur seal diet}

Female Australian fur seals at Kanowna Island and The Skerries have a broad prey base of at least 45 species (38 fish, 7 cephalopods), of which 5 occur in $>10 \%$ of samples. Despite the wide variety of prey recorded, 8 species made up over $80 \%$ of the estimated dietary biomass (Table 4), a finding consistent with previous studies (Gales \& Pemberton 1994, Hume et al. 2004).

\section{Seasonal variation}

There was no clear seasonality in the diet of female Australian fur seals in this study. Prey species fluctuated widely in both frequency of occurrence and 


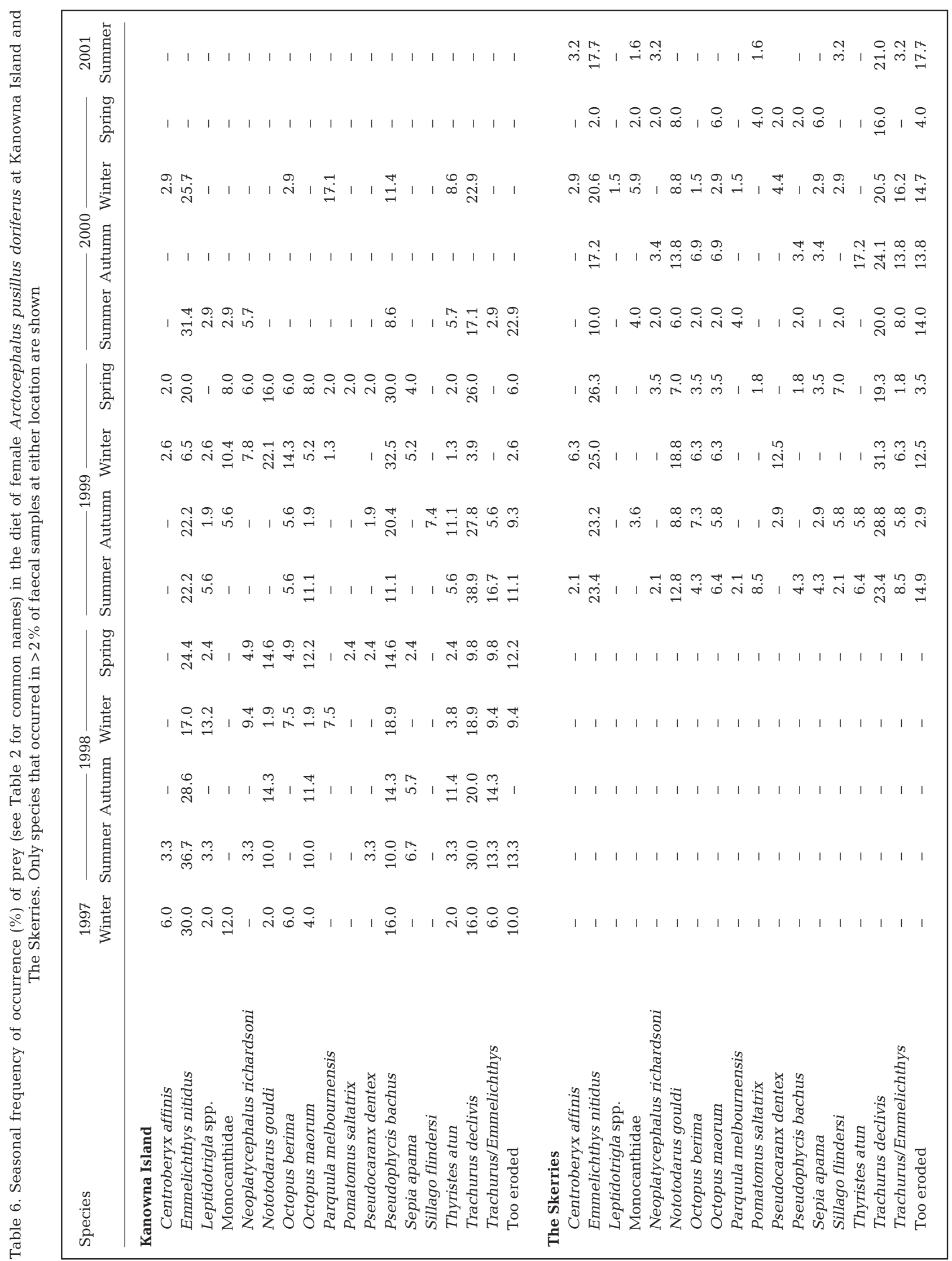


proportion of biomass within and between seasons (Table 6). Prey species did not show detectable seasonal variation despite known seasonal fluctuations of prey availability for a number of species. For example, Southern calamari Sepioteuthis australis form breeding aggregations off the coast of Victoria during August and January (Kailola et al. 1993) yet consistently made up only about $1 \%$ of the seal diet throughout the year. This contrasts with Gales \& Pemberton (1994), who found an increase in the occurrence of cephalopods in the diet of Australian fur seals in southern Bass Strait during January. This increase coincided with the spawning period of the main cephalopod prey species in that area and suggested that seals feed on aggregations of dead and dying cephalopods during this period. An inability to detect seasonal patterns, such as the one above, may also be due to biases caused by the timing of sample collection and researchers missing peaks in the abundance of certain prey.

There is some evidence that other otariid seals feed opportunistically on the most common prey species available at a given time in a particular location. Lactating female Antarctic fur seals in South Georgia feed almost exclusively on mature krill during the summer when the prey are very abundant, with fish increasing in importance towards winter (Reid \& Arnould 1996). Harcourt et al. (2002) also found seasonal differences in the diet of New Zealand fur seals, with females consuming predominantly Gould's squid during summer and autumn but a greater diversity of prey in winter. The lack of seasonal trends in our study may be attributed to the Australian fur seal maintaining a broad prey base (typical of a demersal predator) throughout the year regardless of locally abundant species.

Some prey species, i.e. those that grow relatively more rapidly, were found to vary seasonally in size in the seals' diet. Jack mackerel and redbait showed seasonal fluctuations in size that corresponded to their being rapid-growing species; both species reach a fork length of approximately 19 to $23 \mathrm{~cm}$ by 2 yr of age (Kailola et al. 1993, Furlani et al. 2000). Tiger flathead grow more slowly, taking 4 to $5 \mathrm{yr}$ to reach a total length of about $30 \mathrm{~cm}$ (Kailola et al. 1993), and no seasonal size variation in the seals' diet was apparent. These findings suggest that female Australian fur seals target fish as a function of availability as opposed to selecting prey of specific size classes.

\section{Spatial variation}

Proximity to the shelf edge was not reflected in site differences in prey species in the diet of female Australian fur seals. Rather, the majority of prey species consumed at both Kanowna and The Skerries are considered to occupy a marine demersal habitat in relatively shallow waters less than $100 \mathrm{~m}$ deep (Kailola et al. 1993). In terms of biomass, the most important species (jack mackerel) is found primarily in the water column. Most striking perhaps is the absolute lack of myctophids, an important prey for many fur seal species, or other offshore species in the diet of seals. These findings are consistent with the diving behaviour of female Australian fur seals from Kanowna Island (Arnould \& Hindell 2001) and suggest that females from The Skerries also forage on the benthic and neritic species of the continental shelf. Indeed, the similarities in the occurrence and relative abundance of prey species in the diet of seals from both colonies suggest that they are foraging in similar types of habitats. Female Australian fur seals are capable of foraging up to $500 \mathrm{~km}$ from their natal colony (Littnan \& Arnould 2002) and, as The Skerries and Kanowna Island are only around $250 \mathrm{~km}$ apart, there is the potential for a high degree of overlap in foraging habitats.

This wide-ranging generalist demersal-neritic predation is in contrast to that observed in most other arctocephaline species and is more analogous to the foraging ecology of some sea lion species (Gales \& Mattlin 1997, Merrick \& Loughlin 1997, Thompson et al. 1998). Kanowna Island seals might have been expected to forage on-shelf given their proximity to this region and remoteness from the shelf edge, particularly since fur seals are likely to expend more energy when they are swimming to distant foraging grounds in search of prey relative to using more proximal nearshore environments (Orians \& Pearson 1979). Females from The Skerries, however, might have been expected to feed on pelagic species off the nearby shelf edge/slope. The lactating females may benefit by exploiting shelf-edge and pelagic foraging grounds if these regions were more fruitful than the demersal habitats of the continental shelf. However, they did not. So why do Australian fur seals expend nearly all of their foraging effort on the shelf and on demersal prey?

Bass Strait is a shallow basin dividing mainland Australia from the island of Tasmania (Fig. 1). The shallow waters are influenced primarily by the Tasman Sea and the East Australian Current to the east, and the colder, more enriched sub-Antarctic waters of the Southern Ocean to the south and west. While seasonal upwelling occurs on both the eastern and western rims of the basin, coastal and offshore waters are characterised by low nutrient concentrations (Gibbs et al. 1986). Bass Strait is subject to different water masses affecting the area at different times of the year. In winter, cooler water from the west is pushed in by strong westerly winds, while in the summer, mixed East Australian Current and sub-Antarctic waters flow intermit- 
tently onto the shelf (Bax et al. 2000). The fluctuations in water masses are typically consistent between years, even in periods of El Niño-Southern Oscillation events, as is both primary and secondary productivity (Bax et al. 2000). Thus it appears that drastic changes in environmental conditions necessary to displace species, particularly benthic species, do not occur in Bass Strait.

With this in mind, the relatively unusual foraging strategy of female Australian fur seals appears to be suited for the available environment. There are approximately $192000 \mathrm{~km}^{2}$ of shelf area available for foraging by Australian fur seals. This large, environmentally stable area with relatively wide- and evenly spread prey (Williams et al. 2000) potentially provides a more consistently profitable food reserve than coastal upwelling regions, which are limited in their value due to their distance from some colonies and, possibly more importantly, their predictability. Gende \& Sigler (2006) assessed this issue for Steller sea lions Eumetopias jubatus and demonstrated that an important characteristic of pelagic hot spots being utilised by this species was their persistence. Greater persistence allows predators to predict their location and, as a result, more effectively concentrate search efforts. By utilising reliable foraging habitats, female Australian fur seals may minimise their search effort, foraging trip durations, or distance they must travel and maximise their foraging success, thus maximising milk delivery rates to their pups (Georges et al. 2000).

Like other fur seals, Australian fur seals are generalist predators that feed on a broad range of fish and cephalopods; however, unlike their congeners, no distinct seasonal or spatial trends in diet composition have been identified for some populations of Australian fur seals. The lack of identifiable trends in diet might be the result of a combination of the large number of prey species, limited sample size, and erosion of hard prey remains during foraging trips, all contributing to a reduction in the sensitivity of the faecal analysis. Improved accounting of the diet of this species, which is currently recovering from past exploitation with individual colonies increasing between 2 and $20 \% \mathrm{yr}^{-1}$ (Kirkwood et al. 2005), is necessary to better understand the role of the Australian fur seal in the Bass Strait marine ecosystem. Consequently, the effectiveness of alternative or complementary analytical techniques needs to be investigated.

Acknowledgements. We thank the many outstanding field researchers who assisted with sample collection, in particular S. Allen, P. Barker, C. Bradshaw, M. Chambers, S. Jadhav, P. Mitchell, T. Mitchell, A. Morrisey, B. Priest, S. Robinson, C. Teuffer, E. Turner, J. Tripovich, and K. Willis. We also thank P. Mitchell and C. Teuffer for their meticulous work cleaning samples in the lab. D. Furlani, F. Hume, and M. Norman gave much appreciated guidance in the identification of prey remains. Finally, thanks to B. Page for assistance with the map and to 3 anonymous reviewers for greatly improving this manuscript. Funding for this project was provided by the PADI Foundation, Australian Geographic, and the Macquarie University Postgraduate Research Fund. All research was conducted in accordance with Macquarie University's Animal Care and Ethics Committee guidelines.

\section{LITERATURE CITED}

Antonelis GA, Stewart BS, Perryman WF (1990) Foraging characteristics of female northern fur seals and California sea lions. Can J Zool 68:150-158

Arnould JPY, Hindell MA (2001) Dive behaviour, foraging locations, and maternal-attendance patterns of Australian fur seals (Arctocephalus pusillus doriferus). Can J Zool 79: $35-48$

Bax N, Williams A, Davenport S (2000) Physical oceanography. In: Bax NJ, Williams A (eds) Habitat and fisheries production in the south east fishery ecosystem. Fisheries Research and Development Corporation, Canberra

Bigg MA, Fawcett I (1985) Two biases in diet determination of northern fur seals (Callorhinus ursinus). In: Beddington JR, Beverton RJ, Lavigne DM (eds) Marine mammals and fisheries. George, Allen \& Unwin, London, p 161-208

Bonner WN (1984) Lactation strategies in pinnipeds: problems for a marine mammalian group. Symp Zool Soc Lond 51:257-272

Boyd IL (1996) Temporal scales of foraging in a marine predator. Ecology 77:426-434

Clark KR, Warwick RM (1994) Primer user manual. Plymouth Marine Laboratory, Plymouth

Clarke MR (1986) A handbook for the identification of squid beaks. Clarendon Press, Oxford

Costa DP, Gales NJ (2003) Energetics of a benthic diver: seasonal foraging ecology of the Australian sea lion, Neophoca cinerea. Ecol Monogr 73:27-43

Croxall JP, Everson I, Kooyman GL, Rickets C, Davis RW (1985) Fur seal diving behaviour in relation to vertical distribution of krill. J Anim Ecol 54:1-8

Dellinger T, Trillmich F (1999) Fish prey of the sympatric Galapagos fur seals and sea lions: seasonal variation and niche separation. Can J Zool 77:1204-1216

Furlani D, Williams A, Bax N (2000) Fish biology (length and age). In: Bax NJ, Williams A (eds) Habitat and fisheries production in the south east fishery ecosystem. Fisheries Research and Development Corporation, Canberra

Gales NJ, Cheal AJ (1992) Estimating the diet composition of the Australian sea lion (Neophoca cinerea) from scat analysis: an unreliable technique. Wildl Res 19:405-416

Gales NJ, Mattlin RH (1997) Summer diving behaviour of lactating New Zealand sea lions, Phocarctos hookeri. Can J Zool 75:1695-1706

Gales R, Pemberton D (1994) Diet of the Australian fur seal in Tasmania. Aust J Mar Freshw Res 45:653-664

Gales R, Pemberton D, Lu CC, Clarke MR (1993) Cephalopod diet of the Australian fur seal: variation due to location, season and sample type. Aust J Mar Freshw Res 44: $657-671$

Gende SM, Sigler MF (2006) Persistence of forage fish 'hot spots' and its association with foraging Steller sea lions (Eumetopias jubatus) in southeast Alaska. Deep-Sea Res II 53:432-441

Georges JY, Bonadonna F, Guinet C (2000) Foraging habitat 
and diving activity of lactating Subantarctic fur seals in relation to sea-surface temperatures at Amsterdam Island. Mar Ecol Prog Ser 196:291-304

Gibbs CF, Tomczak M, Longmore AR (1986) The nutrient regime of Bass Strait. Aust J Mar Freshw Res 37:451-466

Green KR, Slip DJ, Moore GJ (1998) The take of fish species by seabirds and marine mammals in the Australian Fisheries Zone around Heard Island: the potential for competition with a commercial fishery. Polar Biol 20:273-280

Harcourt RG, Bradshaw CJA, Dickson K, Davis LS (2002) Foraging ecology of a generalist predator, the female New Zealand fur seal. Mar Ecol Prog Ser 227:11-24

Hume F, Hindell MA, Pemberton D, Gales R (2004) Spatial and temporal variation in the diet of a high trophic level predator, the Australian fur seal (Arctocephalus pusillus doriferus). Mar Biol 144:407-415

Kailola PJ, Williams MJ, Stewart PC, Reichelt RE, McNee A, Grieve C (1993) Australian fisheries resources. BRS and Fisheries Research and Development Corporation, Canberra

Kirkwood RN, Gales N, Lynch M, Dann P (2002) Satellite tracker deployments on adult male Australian fur seals. Arctocephalus pusillus doriferus: methods and preliminary results. Aust Mammal 24:73-83

Kirkwood R, Gales R, Terauds A, Arnould JPY, Pemberton P, Shaughnessy PD, Mitchell AT, Gibbens J (2005) Pup production and population trends of the Australian fur seal. Mar Mamm Sci 21(2):260-282

Lalas C (1997) Prey of Hooker's sea lions, Phocarctos hookeri, based at Otago Peninsula, New Zealand. In: Hindell M, Kemper C (eds) Marine mammal research in the southern hemisphere, Vol 1: Status, ecology and medicine. Surrey, Beatty \& Sons, Chipping Norton, p 130-136

Lea MA, Cherel Y, Guinet C, Nichols PD (2002) Antarctic fur seals foraging in the Polar Frontal Zone: interannual shifts in diet as shown from faecal and fatty acid analyses. Mar Ecol Prog Ser 245:281-297

Editorial responsibility: Otto Kinne (Editor-in-Chief), Oldendorf/Luhe, Germany
Lewis F (1930) Seals on the Victorian coast and their feeding habits. Aust Mus Mag 4:39-44

Littnan CL, Arnould JPY (2002) At-sea movements of female Australian fur seals, Arctocephalus pusillus doriferus. Aust Mammal 24:65-72

Manly BFJ (1997) Randomization, bootstrap and Monte Carlo methods in biology. Chapman \& Hall, London

Merrick RL, Loughlin TR (1997) Foraging behaviour of adult female and young-of-the-year Steller sea lions in Alaskan waters. Can J Zool 75:776-786

Ochoa-Acuña H, Francis JM (1995) Spring and summer prey of the Juan Fernandez fur seal, Arctocephalus philippii. Can J Zool 73:1444-1452

Orians GH, Pearson NE (1979) On the theory of central place foraging. In: Horn DJ, Mitchell RD, Stairs GR (eds) Analysis of ecological systems. Ohio State University Press, Columbus, OH, p 154-177

Pierce GJ, Boyle PR (1991) A review of methods for diet analysis in piscivorous marine mammals. Oceanogr Mar Biol Annu Rev 29:409-486

Reid K, Arnould JPY (1996) The diet of Antarctic fur seals Arctocephalus gazella during the breeding season at South Georgia. Polar Biol 16:105-114

Renouf D (1991) (ed) The behavior of pinnipeds. Chapman \& Hall, London

Schahinger RB (1987) Structure of coastal upwelling events observed off the south-east coast of South Australia during February 1983-April 1984. Aust J Mar Freshw Res 38: $439-459$

Thompson D, Duck CD, McConnell BJ, Garret J (1998) Foraging behaviour and diet of lactating female southern sea lions (Otaria flavescens) in the Falkland Islands. J Zool 246:135-146

Williams A, Bax N, Gowlett-Holmes K (2000) Biological communities. In: Bax NJ, Williams A (eds) Habitat and fisheries production in the south east fishery ecosystem. Fisheries Research and Development Corporation, Canberra

Submitted: March 29, 2006; Accepted: October 25, 2006 Proofs received from author(s): May 4, 2007 